\title{
THE COVID PANDEMIC: TESTING THE RESILIENCE OF THE UNITED STATES, CHINA AND INDONESIA CAPITAL MARKETS
}

\author{
Achmad Agus Priyono ${ }^{1}$ \\ Universitas Islam Malang, Malang, Indonesia \\ aapuim@unisma.ac.id \\ Ety Saraswati $^{2}$ \\ Universitas Islam Malang, Malang, Indonesia \\ etysaraswati@unisma.ac.id
}

\begin{abstract}
There are two main factors that influence the rise and fall of the index, namely internal factors and external factors. The external factor currently experiencing volatility in the stock market is the coronavirus outbreak. Where the presence of the Coronavirus on this earth has caused panic in various parts of the world. The epidemic attacks various levels of society, especially for those who have congenital diseases. This study aims to analyze the resilience of the capital markets in the United States, China and Indonesia in the 60 days before and after the positive confirmation of COVID-19 in each country. The variable of capital market resilience in the United States is used as a proxy for the DJI index, while the resilience of the capital market in China is used as a proxy for the SSEC index, while the resilience of the capital market in Indonesia is used as a proxy for the IDX index. The paper tries to determine whether there are differences in the resilience of the capital market before and before the covid outbreak in the American, Chinese and Indonesian capital markets. The results of the study prove that the Covid outbreak has had a very bad impact on the stock markets of Indonesia and the United States. The tool on the test used to prove that there is a difference in resilience in the capital markets in Indonesia and the United States in the 60 days before and after being confirmed positive for Covid. Meanwhile, in the capital market in China, it was found that there was no difference in the resilience of the capital market in the 60 days before and before being confirmed positive for Covid. This condition proves the country's success in handling and controlling the covid outbreak.
\end{abstract}

Keywords: Covid, DJI, SSEC, IDX 


\section{INTRODUCTION}

The capital market plays an essential role in the economy of a country. The United States (USA), the country with the enormous economic power in the world, has four main indexes and eight additional indexes. Meanwhile, the bamboo curtain country with the second-largest financial strength globally has three main indexes and five additional indexes. Indonesia, a developing country, has one main index and four additional indexes (Indeks Indonesia - Investing.com, 2021).

One of the stock indexes that is always a concern and reference by brokers in superpower countries is the Dow Jones Industrial Average (DJI). DJI is the oldest index and performs very well. For the first time, the index consisted of only 12 issuers, but in line with economic developments, the DJI index also grew and replaced consumer and technology companies. Meanwhile, one of the most extensive indexes used as a reference in China is the Shanghai Composite Index (SSEC). SSEC is an index of stocks traded on an exchange on the Shanghai Stock Exchange. The SSEC index is used as an authoritative statistical index widely followed at home and abroad to measure the performance of the Chinese Capital Market. In Indonesia, the only primary index is the Jakarta Stock Exchange Composite (IDX). The IDX index measures all shares traded on the Indonesia Stock Exchange (IDX) (“DJI,” 2021; “SSEC,” 2021).

Two main factors influence the rise and fall of the index, namely internal factors, and external factors. The external factor currently whacking the volatility in the stock market is the presence of the coronavirus outbreak. The presence of the Coronavirus on this earth has caused panic in various parts of the world. The epidemic attacks multiple levels of society, especially for those who have congenital diseases. The presence of the virus was detected for the first time in the city of Wuhan, China, on December $31^{\text {st }}$, 2019, cases of pneumonia were found. Furthermore, on January $1^{\text {st }}$, 2020, the town was closed for sanitation and disinfection. However, the lockdown in Wuhan and other cities in China were unable to stem the spread of the virus throughout the world (WHO Timeline COVID-19, 2020).

The risk of death due to being infected with the covid virus is very low compared to other viruses that have become pandemics. However, the effectiveness of the virus to spread is very high, as illustrated in table 1 below: 
Table 1

Comparison between Death Toll and Infection Toll Covid Epidemic with the Other Epidemic

\begin{tabular}{|l|l|l|}
\hline Epidemic & Mortality rate (Death/Case) & Infection rate (Per Infected Person) \\
\hline Ebola & $50 \%$ & $1,5-2,5 \%$ \\
\hline MERS & $34,30 \%$ & $0,42-0,92 \%$ \\
\hline SARS & $10 \%$ & $3 \%$ \\
\hline COVID-19 & $1 \%-3.4 \%$ & $1.5-3.5 \%$ \\
\hline Seasonal flu & $1 \%-3.4 \%$ & $1.3 \%$ \\
\hline
\end{tabular}

Source: (Abiad et al., 2020)

The spread of the coronavirus has reached almost all countries in the world. The United States recorded its first case on January $21^{\text {st }}, 2020$, while Indonesia reported its first case on March $2^{\text {nd }}, 2020$. However, the spread of the virus continues throughout the world, reported being affected by the outbreak (Priyono, 2021). The total number of Covid-19 cases globally has reached 223.4 million positive cases with a total death of 4.6 million. Of these total cases, America became the first largest center of the spread of COVID with 41.4 million positive cases and total death of 441,782 people. Meanwhile, Indonesia was ranked $13^{\text {th }}$ of COVID cases, with 4.2 million positive cases and 141,826 dead people. However, China was reported as the source of COVID-19, ranked 109th of COVID-19, with 95,111 positive cases and total death of 4,636 (Worldometer, 2021).

\section{Figure 1 \\ World Number of Positive Covid 19 Cases}

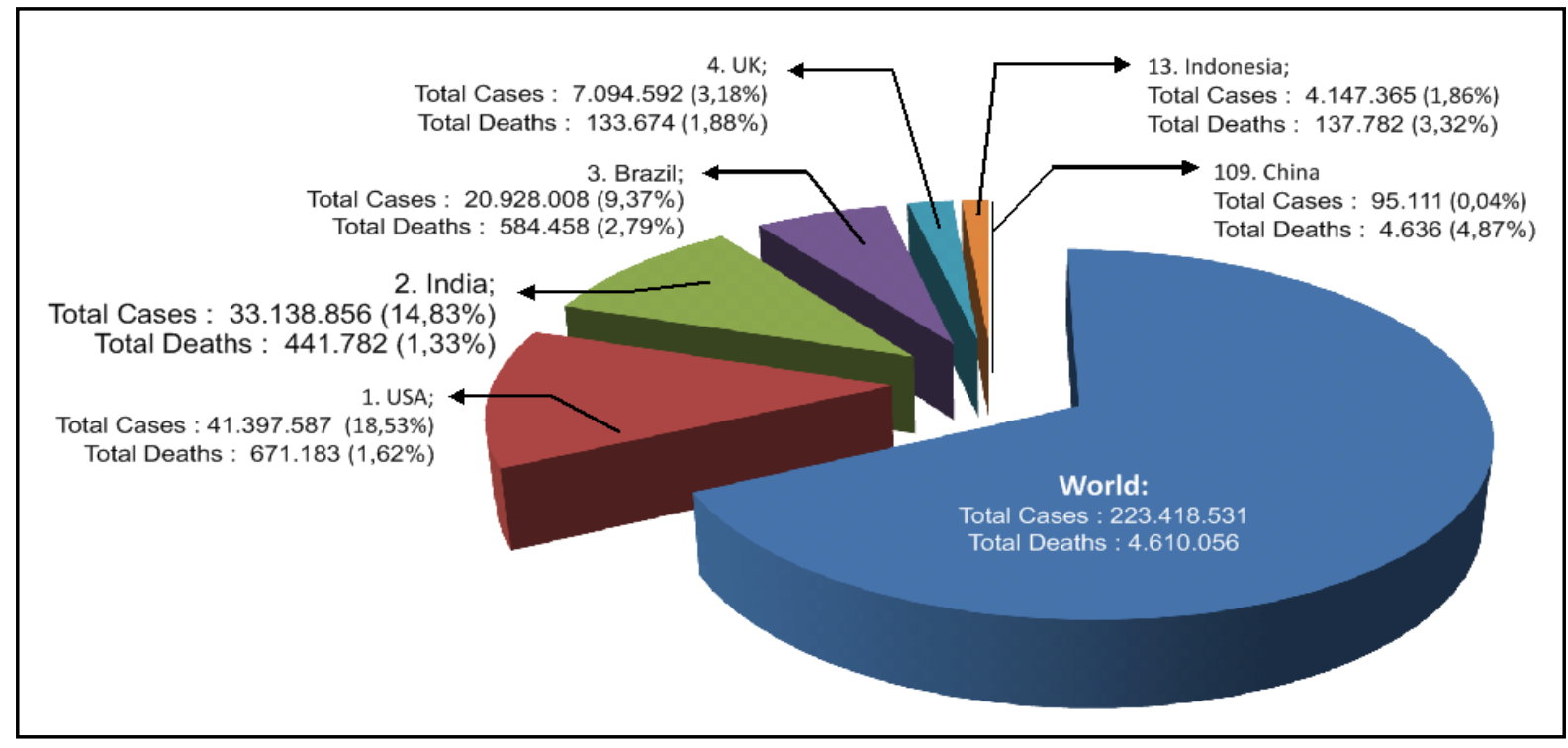

Source: Worldometer, 2021 
The spread of the virus did not stop there because the virus was able to mutate into new, more virulent variants. The World Health Organization reports that 11 new variants of the corona virus have a vaccine-resistant effect and are more deadly (Mediatama, 2020).

No drug is clinically able to treat the effects of the virus. Even the administration of a vaccine does not guarantee a person is immune to the virus. The vaccine's effectiveness is only around $62 \%$ - 95\%, even some of the circulating vaccines have yet to be tested their effectiveness. For now, prevention is the alternative treatment for the epidemic (Gallagher, 2021). Some of the affected countries have restricted social activities of the community through regional lockdowns and by implementing health protocols in social life to prevent the spread of the epidemic,

The lockdown of the affected areas harms the limitation of community mobilization and the business world, impacting economic growth.

Figure 2

Gross Domestic Product, Current Prices (National Currency)

(Billions U.S. Dollars)

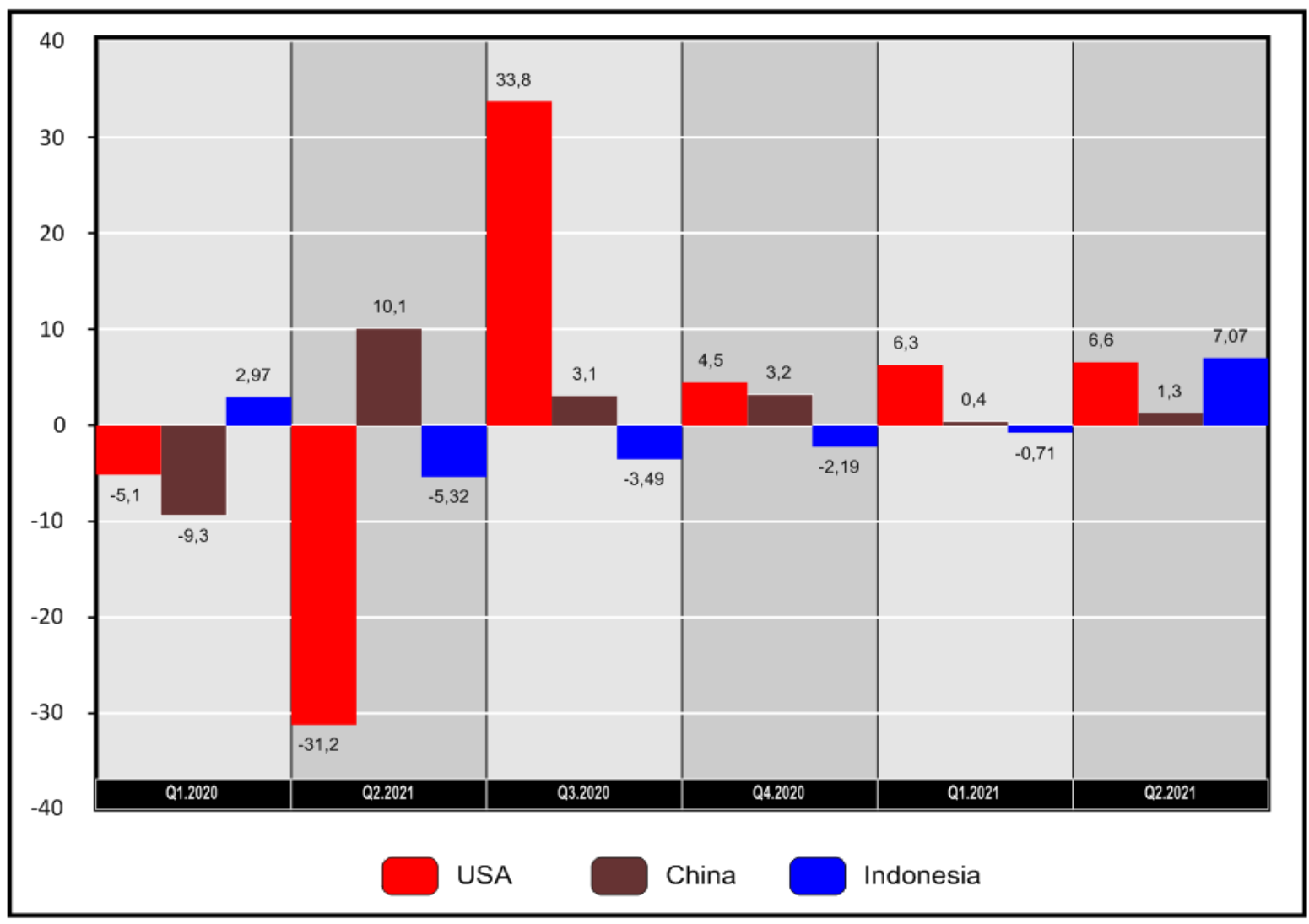

Source: https://id.tradingeconomics.com, 2021 
The COVID-19 outbreak devastated the United States' economic growth in the first and second quarters of 2020. The first quarter the country's economic growth slowed by $-5.1 \%$, and in the second quarter, it fell by $-31.2 \%$. Meanwhile, China's economic growth in the first quarter of 2020 experienced a slowdown by $-9.3 \%$, but in the next quarter continued to recover despite the uneven growth rate. The impact of Covid on Indonesia's economic growth will be felt in the second quarter of 2020 until the first quarter of 2021. In the second quarter of 2021, the Indonesian economy began to rise with an indicated growth of $7.07 \%$.

The slowdown in economic growth marked by the decline in the gross domestic product was intensely felt by various public sectors and the business world by this global event, including the worldwide stock market, including the stock exchanges in the United States and China, and even the stock exchange in Indonesia. The covid pandemic has had a severe impact on the performance of the capital market, as reflected in the following graph:

Figure 3

The Movement of the Dow Jones Industrial Average (DJI), SZSE Component (SZI), and Jakarta Stock Exchange Composite (IDX) October 2019 - December 2020

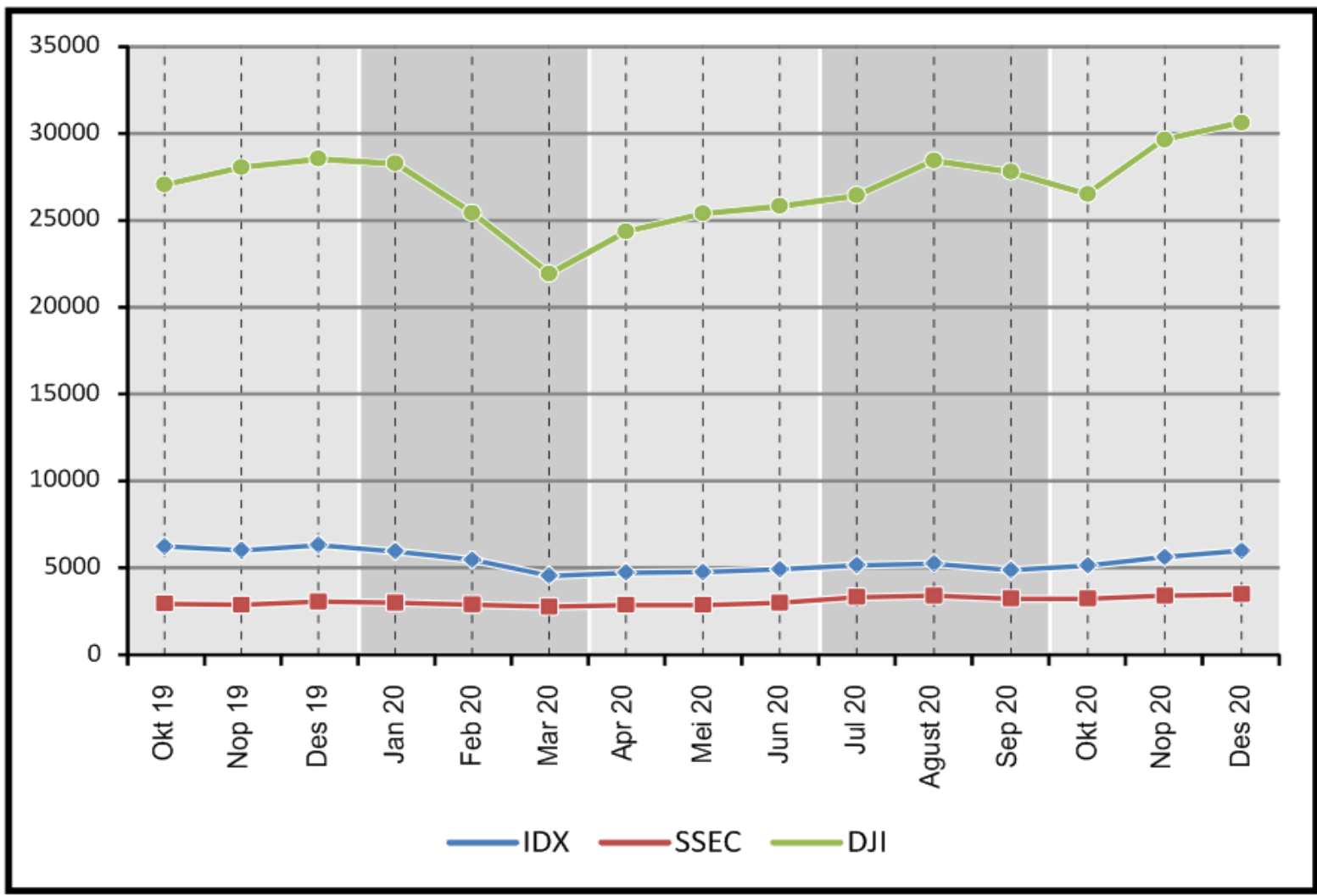

Source: Indeks Indonesia, 2021 


\section{REVIEW OF LITERATURE}

Coronavirus is a virus that infects the respiratory system. In addition to the Coronavirus or SARS-CoV-2, viruses that fall into this group include the virus that causes Severe Acute Respiratory Syndrome (SARS) and the virus that causes Middle-East Respiratory Syndrome (MERS). What distinguish it from the coronavirus are the speed of its spread and the severity of symptoms.

\section{Signaling Theory}

The absence of information equality/information asymmetry impacts the difference in the information held about the company between management and investors. Encourages the emergence of Signaling Theory, where management and shareholders expect to have equal input. Management will send relevant signals related to the condition of the company to investors. The information sent by the administration is an important signal for investors, and then investors will process the signal for decision making.

Brigham et al., (2014) explain, "Signal Theory is an action taken by the company's management that provides clues to investors about how management views the company's prospects." Meanwhile, Fahmi, (2014) explains that signal theory is a theory that explores stock price fluctuations in the stock market so that it will influence investors. Furthermore, Jogiyanto, (2013) states that the published information will provide a signal for investors in making investment decisions. If the published announcement contains a positive value, it expects the market to react when it receives the information. By the signal theory, companies that have high performance will give a signal about the conditions of companies that are profitable and relatively not easy to go bankrupt and various other forms of financial distress, and vice versa for companies that have low performance. Based on this opinion, it can be concluded that the signal theory explains that companies have the urge to provide financial statement information to external parties.

\section{Stock Index}

Stock Index is a statistical measure that reflects the general price movement of a group of stocks selected according to specific criteria and methods and evaluated periodically (PT Bursa Efek Indonesia, 2021). Meanwhile, Anoraga \& Pakarti, (2001) explain that the IHSG is an index that shows the movement of stock prices in general traded on the stock exchange and becomes a reference related to the development of trading in the 
stock market. Thus, the index is a tool to show each stock's characteristics that have something in common, such as trading shares in the same stock market, belonging to the same industry, or the same market capitalization. In addition, many indexes based on news or financial services use to measure portfolio performance, such as mutual funds. By using the IHSG, investors can evaluate the stock market situation, whether conditions increase or decrease.

\section{Impact of the Virus Outbreak}

The stock index is formed from various economic instruments and also the influence of the non-economic environment. Multiple issues related to the non-economic environment often trigger stock volatility. The capital market is said to be efficient if the prices of securities respond quickly to all events that contain information. And these events occurred beyond the control of the company, including the spread of disease outbreaks.

Previous research was conducted to answer the relationship between disease outbreaks and stock trading. Chen et al., (2020) examined the Positive and Negative Impact of the SARS Outbreak: The Case of the Taiwan Industry. The study results found that the SARS outbreak was proven to affect stock market volatility. Furthermore, Funck \& Gutierrez, (2016) examined the impact of Ebola Virus Disease (EVD) in the African country. His research proves that the EVD outbreak affects the volatility of the flow of funds and market returns.

Furthermore, there are several previous researchers who examined the impact of covid on volatility. Yousfi et al., (2021), who conducted a first comparative assessment of the impact of the first and second waves of the ongoing COVID-19 outbreak on the US and Chinese stock markets. In his research found that (1) There is an overflow of volatility (contagion effect) between the two stock markets, especially during the rapid spread phase of COVID-19 in the US, (2) surface analysis of the news impact correlation shows that shocks in the US and China markets have an asymmetric effect on correlation between the two markets (3) there is a persistent relationship between the US, uncertainty, and the COVID-19 pandemic during the first and second waves of the outbreak, (4) proves that the pandemic has had harmful consequences in general and the US economy in particular.

Wu \& Hui, (2021) analyze the dependency relationship of stock indexes from 10 primary industrial sectors in China during COVID-19. The results show that the 
dependency relationship between Chinese stock sectors increases significantly in the pandemic but decreases in the post-pandemic period. The dependency structure is similar to that during the calm period. In the pandemic period, the dependence between the consumer staples sector and other sectors increased significantly, and the consumer staples sector and the health care sector maintained strong dependencies. From the results of the sliding window, the Chinese stock market is sensitive to the impact of COVID-19, but the duration of the effect of dependence between those stock sectors is not long. The results of that study reinforce by Yan \& Qian, (2020), which states that the Chinese stock market is susceptible. Still, the existence of rapid prevention and control measures affects the duration of the adverse impact of that outbreak does not last long.

Liu et al., (2020) in their research that evaluates the short-term impact of covid on 21 leading stock market indices including: Japan, Korea, Singapore, the United States, Germany, Italy, and England, etc. The finding shows that stock markets in the main affected countries and regions fell rapidly after the virus outbreak. Furthermore, countries in Asia experienced more negative abnormal returns than other countries.

Meanwhile, on the Indonesian stock market, Dewi, (2020), in her study, uses the period from January 13th, 2020, to April 21st, 2020, on the Indonesia Stock Exchange to find that Covid had negative implications for the JCI. Similarly, research conducted by (Junaedi \& Salistia, 2020) finds that the Covid-19 pandemic and social distancing policies (WFH and PSBB) in the country have affected the stock market dynamics.

\section{Event Study Method}

The event study method is a statistical method used to evaluate the impact of an event on firm value. This method was discovered by Ball and Brown in 1968. This method is also widely used to find the effect of an event from various research fields such as accounting or finance, management, marketing, technology and information, law, and political science, management, and operational (“Event study," 2020).

\section{Hypothesis}

To evaluate the impact of covid on stock indices traded on the stock markets of the United States, China, and Indonesia, the researchers used 60 days before the occurrence of covid in those countries and 60 days after the event of covid. Based on theoretical studies and previous research, the hypothesis formulated: 
H1: There is a significant weakness in the USA stock market on the day around the first confirmed COVID-19 announcements in the USA.

$\mathrm{H} 2$ : There is no significant weakness on the day around the announcement of the first confirmed COVID-19 in China.

H3: There is a significant weakness in the Indonesian capital market on the day around the announcement of the first confirmed covid in Indonesia.

\section{RESEARCH METHOD}

The researchers used a quantitative descriptive method to obtain a profile picture, characteristics, and relevant aspects related to stock market phenomena in the United States, China, and Indonesia stock exchanges before and after the pandemic occurred around the first day was confirmed positive.

The statistical test used to test the resilience of the capital market before and after the pandemic occurred around the first day was confirmed positive, namely the Paired Sample t-test. The test was carried out on the DJI index, which represents the United States stock market, the SSEC index, which represents the Chinese stock market, and the IDX index, which is representative of the Indonesian stock market. The time range taken in this study was 60 days before and after being confirmed positive for COVID in each country. The DJI, SSEC, and IDX index data used in this study are secondary data from the https://id.investing.com page.

\section{RESULTS AND DISCUSSION}

\section{Descriptive Statistic}

Based on the stock index data of DJI, SSEC, and IDX 60 days before and after the announcement was confirmed positive, the results of descriptive statistical analysis can be seen as follows:

Table 2

Stock Index Descriptive Statistics Test

\begin{tabular}{|l|l|l|l|l|l|}
\hline & N & Mean & $\begin{array}{l}\text { Std. } \\
\text { Deviation }\end{array}$ & Minimum & Maximum \\
\hline DJI_Before & 60 & 28054,66 & 613,9474 & 26805,53 & 29348,1 \\
\hline DJI_After & 60 & 25343,69 & 3451,636 & 18591,93 & 29551,42 \\
\hline SSEC_Before & 60 & 2945,025 & 42,72754 & 2871,98 & 3040,02 \\
\hline
\end{tabular}




\begin{tabular}{|l|l|l|l|l|l|}
\hline SSEC_After & 60 & 2934,488 & 132,6832 & 2660,17 & 3115,57 \\
\hline IDX_Before & 60 & 6101,472 & 205,2361 & 5452,7 & 6329,31 \\
\hline IDX_After & 60 & 4667,984 & 336,4752 & 3937,63 & 5650,14 \\
\hline
\end{tabular}

Source: SPSS, 2021 (data processed)

The average DJI index 60 days before and after the announcement was confirmed positive in the United States tends to fall to $10.7 \%$. This indicates a decline in the resilience of the stock market in the United States as a result of the COVID-19 pandemic. Meanwhile, the average SSEC index 60 days before and after the announcement was confirmed positive in China tended to fall by $0.36 \%$. This indicates a decline in the resilience of the stock market in China as a result of the COVID-19 pandemic. And the average 60-day IDX index and after the announcement was confirmed positive in Indonesia tended to fall by $30.71 \%$. This indicates a decline in the resilience of the stock market in China as a result of the COVID-19 pandemic. Based on these results, it is proven that Covid has caused a decrease in the resilience of the stock market in the United States, China, and Indonesia.

\section{Normality Test}

Table 3

One-Sample Kolmogorov-Smirnov Test

\begin{tabular}{|l|c|c|c|c|c|c|}
\hline \multirow{2}{*}{} & \multicolumn{2}{|c|}{ DJI Index } & \multicolumn{2}{c|}{ SSEC Index } & \multicolumn{2}{c|}{ IDX Index } \\
\cline { 2 - 7 } & Before & After & Before & After & Before & After \\
\hline N & 60 & 60 & 60 & 60 & 60 & 60 \\
\hline Test Statistic &, 060 &, 167 &, 125 &, 135 &, 166 &, 206 \\
\hline Asymp. Sig. (2-tailed) &, $200^{\mathrm{c}, \mathrm{d}}$ &, $000^{\mathrm{c}}$ &, $021^{\mathrm{c}}$ &, $009^{\mathrm{c}}$ &, $000^{\mathrm{c}}$ &, $000^{\mathrm{c}}$ \\
\hline
\end{tabular}

Source: SPSS, 2021 (data processed)

Based on the results of the normality test using the Kolmogorov-Smirnov test, it can be seen that the significance value of each variable has a significant value less than 0.05 except for the DJI stock index before the onset of covid, so it can be concluded that the data is not normally distributed. This is because the data from each variable in this study fluctuate significantly from day today. Therefore, it is very reasonable if there is an abnormal distribution of data.

The assumption of normality is an assumption that must be met in the paired t-test because this test is a parametric statistical test. However, in this study, 60 days of data were used before and after the first announcement of COVID-19 in each country so that the 
Central Limit Theorem assumption can be used. Based on these assumptions, the premise of normality can be ignored (Gujarati, 2013).

Stock Index Correlation Before and After

Table 4

Paired Samples Correlations

\begin{tabular}{|l|l|l|l|l|}
\hline Stock Index & N & Correlation & Sig. \\
\hline Pair 1 & DJI_Before \& DJI_After & 60 &, 690 &, 000 \\
\hline Pair 2 & SSEC_Before \& SSEC_After & 60 &, 272 &, 036 \\
\hline Pair 3 & IDX_Before \& IDX_After & 60 &,- 471 &, 000 \\
\hline
\end{tabular}

Source: SPSS, 2021 (data processed)

This test is carried out to see whether the stock index 60 days before and before the announcement of the first Covid was confirmed to be correlated with each other or not. The results of the sample testing are as follows: 1) The DJI index before and after the first confirmed covid announcement is obtained a correlation value of 0.690 with a significance level of 0.000 . Thus, it can be concluded that the DJI Index before and after the information of the first covid was confirmed to be correlated with each other at an alpha level of $0.0 \%$; 2) The SSEC index before and after the first confirmed covid announcement is obtained a correlation value of 0.272 with a significance level of 0.036 . Thus, it can be concluded that the SSEC Index before and after the information of the first covid was confirmed to be correlated at an alpha level of $3.6 \%$; 3 ) The IDX index before and after the first confirmed covid announcement is obtained a correlation value of -0.471 with a significance level of 0.000. Thus, it can be concluded that the IDX Index before and after the information of the first covid was confirmed to be correlated with each other at an alpha level of $0.0 \%$.

\section{Different Test T-test (Paired Sample T. Test)}

This test was carried out on two paired samples, namely stock indices before and after the covid announcement. The results of the sample testing are as follows:

Table 5

\section{Paired Sample Test}

\begin{tabular}{|l|c|c|c|c|}
\hline \multicolumn{2}{|c|}{ Stock Index } & t & df & Sig (2-tailed) \\
\hline Pair 1 & DJI_Before - DJI_After & 6,862 & 59 & 0,000 \\
\hline Pair 2 & SSEC_Before- SSEC_After & 0,638 & 59 & 0,526 \\
\hline Pair 3 & IDX_Before - IDX_After & 23,652 & 59 & 0,000 \\
\hline
\end{tabular}

Source: SPSS, 2021 (data processed) 
Based on the results of the Paired Samples Statistics test, it can be concluded that: 1) The DJI index is obtained a test value of 6.862 with a significance level of 0.00 less than 0.05. Based on the significance value, it shows that 60 days before and after the announcement was confirmed positive in the United States, there was a significant difference in the DJI stock index; 2). The SSEC index is obtained a test value of 0.638 with a significance level of 0.526 greater than 0.05 . Based on the significance value, it shows that 60 days before and after the announcement was confirmed positive in China, there was no significant difference in the SSEC stock index; 3) The IDX index is obtained a test value of 23,652 with a significance level of 0.00 less than 0.05. Based on this significance value, it shows that 60 days before and after the announcement was confirmed positive in Indonesia, there was a significant difference in the IDX stock index.

\section{Discussion}

Covid is an extraordinary event that not only affects the health sector but also penetrates into other fields, including the economy. The World Health Organization, on March $11^{\text {th }}$, 2020, officially declared the Covid event as a pandemic (World Health Organization, 2020). The Government of Indonesia, through Presidential Decree No. 12 of 2020 dated April 13 ${ }^{\text {th }}, 2020$, stipulates that the spread of covid is a Non-Natural Disaster (JDIH BPK RI, 2020). The decision was taken because of the increasingly massive spread of the epidemic and is a disaster caused by non-natural events or series of events, which include technological failures, failed modernization, epidemics, and disease outbreaks.

Almost all countries in the world feel the impact of the spread of this epidemic. The United States, which was named a superpower in the first quarter of its economic growth, contracted by $5.1 \%$. Furthermore, in the second quarter, its economic growth fell by $31.2 \%$. The Dow Jones Industrial Average (DJI), which is the world's largest stock market, fell to its lowest level at $18,591.93$ on March $23^{\text {rd }}, 2020$, or 43 days after the first confirmed COVID-19 announcement in America. This country is also considered to have failed to deal with the Covid outbreak and has made this country the center of the largest pandemic in the world.

China, which has the second-largest economic power in the world, also experienced the same thing, where the outbreak caused China's economic growth to contract by $9.3 \%$ in the first quarter. The stringent handling of COVID-19 since the announcement was 
confirmed positive resulted in an increase in its economic growth in the second quarter of 2020 by $10.1 \%$. The Shanghai Composite Stock Index (SSEC) briefly fell at the level of 2,660.17 on March $23^{\text {rd }}, 2020$, or 52 days after the announcement of the first confirmed COVID-19 in China. But gradually, the SSEC index experienced a very significant improvement. The stringent handling of Covid was able to change the position from the initial source country of transmission to the $109^{\text {th }}$ country with a total of 95,111 cases.

Indonesia is the $13^{\text {th }}$ country with a total of $4,147,385$ cases. The COVID-19 pandemic has ravaged economic growth. Where in the first quarter of 2020, Indonesia's economic growth remained at $2.97 \%$, but in the second, third, and fourth quarters, it fell by $5.52 \%, 3.49 \%$, and 2. 19\%. Meanwhile, the IDX (Indonesia Stock Exchange) Index fell to its lowest level of 3937.63 on the $16^{\text {th }}$ day after the first confirmed COVID-19 announcement in Indonesia.

Based on tests on descriptive statistics, the United States stock index (DJI) 60 days before and after the announcement was confirmed positive tended to fall deeper by $10.7 \%$ compared to the Chinese stock index (SSEC), which recorded a decline of only $0.36 \%$. The most significant decline in the 60 days before and after the positive confirmed announcement was recorded on the Indonesian stock market (IDX), which was down by $30.71 \%$.

Based on the results of the different tests using the paired-samples t-test, it proves that: 1) The United States stock index (DJI) has a difference between 60 days before and after the announcement was confirmed positive. This proves that the Covid outbreak has had an impact on trading on the stock market in the United States. This means that economic uncertainty as an implication of the Covid outbreak has an impact on stock trading on the United States stock market. The fall of the DJI Index to 18,591.93 marked a decline to its lowest level since November 2016. The fall of the DJI Index was also accompanied by a fall in the S \& P 500 (SPX) index to 2,237.40, and also the Nasdaq Composite (IXIC) to 6,860.67 is a sign the country's failure to control the spread of the covid outbreak (Imbert, 2020). The results of this study support research conducted by Yousfi et al., (2021), who proved that the pandemic had shown harmful consequences for financial markets in general and the US economy in particular; 2) China stock index (SSEC) has no difference between 60 days before and after the announcement was 
confirmed positive. This proves that the covid outbreak has no impact on trading on the stock market in China. This means that economic uncertainty as an implication of the Covid outbreak has no impact on stock trading on the Chinese stock market. The results of this study are in line with research conducted by Wu \& Hui, (2021); and Yan \& Qian, (2020), who stated that the Chinese stock market was very sensitive to the impact of covid, but the duration of the impact did not last long, which could indicate that the pandemic prevention and control measures implemented in China were effective and on time; 3) The Indonesian stock index (IDX) has a difference between 60 days before and after the announcement was confirmed positive. This proves that the Covid outbreak has had a major impact on trading on the stock market in Indonesia. This means that economic uncertainty as an implication of the Covid outbreak has an impact on stock trading on the Indonesian stock market. This research supports research conducted by Dewi, (2020); and Junaedi \& Salistia, (2020), who found that the Covid-19 pandemic had negative implications for the IHSG, and domestic social distancing policies (WFH and PSBB) had affected the dynamics of the stock market.

\section{CONCLUSION}

The results showed that the covid outbreak had a negative impact on the stock markets of the United States, China, and Indonesia. The Indonesian and United States capital markets tend to respond more deeply to these events than the Chinese capital markets. Based on the paired-sample t-test, it proves that there was a weakening of resilience in the Indonesian and United States capital markets 60 days before and before the announcement was confirmed positive in each of these countries. Meanwhile, the Chinese stock market has strong resilience to the COVID-19 pandemic; as evidenced by this, there are no difference 60 days before and before the announcement was confirmed positive in China.

\section{REFERENCES}

Abiad, A., Arao, R. M., \& Dagli, S. (2020). The Economic Impact of the COVID-19 Outbreak on Developing Asia (Bangladesh, China, People's Republic of, Philippines; Issue 128). Asian Development Bank. https://www.adb.org/publications/economic-impact-covid19-developing-asia. 
Anoraga, P., \& Pakarti, P. (2001). Pengantar Pasar Modal. Rineka Cipta.

Brigham, E. F., Houston, J. F., \& Yulianto, A. A. (2014). Dasar-dasar manajemen keuangan edisi 11-buku 1 (Essential of financial management) (11th ed.). Salemba 4 Jakarta.

Chen, J., Shi, J., Yau, T., Liu, C., Li, X., Zhao, Q., Ruan, J., \& Gao, S. (2020). Bioinformatics analysis of the Wuhan 2019 human coronavirus genome. Chinese Journal of Bioinformatics, 18(2), 96-102. https://doi.org/10.12113/202001007.

Dewi, C. K. (2020). Jkse And Trading Activities Before After Covid-19 Outbreak. RJABM (Research Journal of Accounting and Business Management), 4(1), 1-6. https://doi.org/10.31293/rjabm.v4i1.4671.

DJI. (2021). In Wikipedia bahasa Indonesia, ensiklopedia bebas. https://id.wikipedia.org/w/index.php?title=Dow_Jones_Industrial_Average\&oldid= 18483040 .

Event study. (2020). In Wikipedia. https://en.wikipedia.org/w/index.php?title=Event_study\&oldid=992063085.

Fahmi, I. (2014). Manajemen Keuangan Perusahaan dan Pasar Modal (1st ed.). Mitra Wacana Media, Jakarta.

Funck, M., \& Gutierrez, J. A. (2016). Has Ebola Infected the Market: A Contagious Reaction to a (Media) Health Care Crisis? (SSRN Scholarly Paper ID 2786001). Social Science Research Network. https://doi.org/10.2139/ssrn.2786001.

Gallagher, J. (2021, January 31). Vaksin Covid-19 apa saja yang terbukti bekerja? BBC News Indonesia. https://www.bbc.com/indonesia/dunia-55876137.

Gujarati, D. (2013). Dasar-Dasar Ekonometrika. Erlangga.

Imbert, F. (2020, March 22). CNBC. CNBC. https://www.cnbc.com/2020/03/22/stockmarket-futures-open-to-close-news.html.

Indeks Indonesia-Investing.com. (2021). Investing.com Indonesia. https://id.investing.com/indices/indonesia-indices.

Indonesia GDP Annual Growth Rate | 2000-2021 Data| 2022-2023 Forecast | Calendar. (2021). https://tradingeconomics.com/indonesia/gdp-growth-annual.

Investing.com-Stock Market Quotes \& Financial News. (2021, September 7). https://www.investing.com/.

JDIH BPK RI. (2020). https://peraturan.bpk.go.id/Home/Details/135718/keppres-no-12tahun-2020.

Jogiyanto, H. (2013). Teori Portofolio dan Analisis Investasi (8th ed.). BPFE Yogyakarta. 
Junaedi, D., \& Salistia, F. (2020). Dampak Pandemi Covid-19 terhadap Pasar Modal di Indonesia. Al-Kharaj : Jurnal Ekonomi, Keuangan \& Bisnis Syariah, 2(2), 109-131. https://doi.org/10.47467/alkharaj.v2i2.112.

Liu, H., Manzoor, A., Wang, C., Zhang, L., \& Manzoor, Z. (2020). The COVID-19 Outbreak and Affected Countries Stock Markets Response. International Journal of Environmental Research and Public Health, 17(8), 2800. https://doi.org/10.3390/ijerph17082800.

Mediatama, G. (2020, December 15). Tiga faktor ini bakal mempengaruhi pergerakan IHSG tahun depan. kontan.co.id. https://investasi.kontan.co.id/news/tiga-faktor-inibakal-mempengaruhi-pergerakan-ihsg-tahun-depan.

PT Bursa Efek Indonesia. (2021). PT Bursa Efek Indonesia. https://www.idx.co.id/datapasar/data-saham/indeks-saham/.

Priyono, A., \& Kartiko, A. (2021). The Effect of Covid-19, Rupiah Exchange Rate, and Inflation on the Indonesia Sharia Stock Index during the Covid-19 Pandemic. Indonesian Interdisciplinary Journal of Sharia Economics (IIJSE), 4(1), 313-336. https://doi.org/10.31538/iijse.v4i1.1654.

SSEC. (2021). In Wikipedia bahasa Indonesia, ensiklopedia bebas. https://id.wikipedia.org/w/index.php?title=Indeks_Komposit_SSE\&oldid=1801170 5.

WHO Timeline-COVID-19. (2020, April 27). https://www.who.int/news/item/27-04-2020who-timeline---covid-19.

Worldometer.

(2021,

September

30). https://www.worldometers.info/coronavirus/\#countries.

Wu, X., \& Hui, X. (2021). The Impact of COVID-19 on the Dependence of Chinese Stock Market. Discrete Dynamics in Nature and Society, 2021, e5588562. https://doi.org/10.1155/2021/5588562.

Yan, L., \& Qian, Y. (2020). The Impact of COVID-19 on the Chinese Stock Market: An Event Study Based on the Consumer Industry. Asian Economics Letters, 1(3), 18068. https://doi.org/10.46557/001c. 18068.

Yousfi, M., Ben Zaied, Y., Ben Cheikh, N., Ben Lahouel, B., \& Bouzgarrou, H. (2021). Effects of the COVID-19 pandemic on the US stock market and uncertainty: A comparative assessment between the first and second waves. Technological $\begin{array}{lllll}\text { Forecasting } \quad \text { and Social } & 120710 .\end{array}$ https://doi.org/10.1016/j.techfore.2021.120710. 